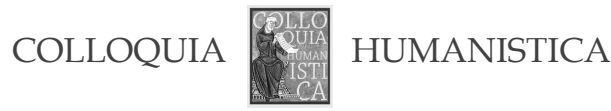

Irena Sawicka

Institute of Slavic Philology

Nicolaus Copernicus University

Toruń

\title{
Continuity or Discontinuity - the Case of Macedonian Phonetics
}

$\mathrm{T}$ There is no better language level than phonetics to exemplify the problem in question and there is no better language than Macedonian to do this. As far as phonetics is concerned, the Macedonian linguistic area constitutes the Balkan melting pot. Statistics reveal more than 25 nations in the small Republic of Macedonia, which makes it an exceptionally diversified melting pot in every respect. Here we find a concentration of all phonetic balkanisms. More precisely, it is the area where Greek, Albanian and Macedonian meet. This juncture should be treated as the centre of the phonetic Balkan Sprachbund.

Phonetics, more than any other level of language organization, reveals the continuity or discontinuity of various processes in the multilinguistic context. This is because phonetic convergence proceeds in a different way than grammatical convergence. In both cases, the form itself is the starting point, but as regards grammatical features, the form is accompanied by function. Thanks to this, the form easily stabilizes. Morphosyntactic convergence occurs when a language uses its own inventory of morphemes, choosing the ones which speakers find equivalent to the forms of the language in contact. They try to use them in the same way as in the other language and in time the function of such forms gramaticalizes and becomes the same or similar in both languages. Consequently, when a language borrows a form, it also borrows or modifies a grammatical category. Phonetic convergence is usually restricted to pure form, without functional interference - functional equivalence is rare at this level. This makes it very difficult to build a holistic description of a Sprachbund. 
The key is thus a physical similarity, which is the starting point, while the target is a complete unification of the form. The form may play different functions in particular systems. However, a striking fact is that phonetic convergence between Macedonian dialects and coexisting Albanian or Greek dialects seems to be deeper than in the remaining Balkan territory. At least such is the present day picture.

Knowing the mechanism of phonetic convergence, which has, first of all, surface character, we may expect that it will proceed faster than grammatical convergence and that its results may not be stable. Some facts known from the historical phonetics of the Balkanic languages confirm this conclusion. What we observe sometimes is a fluctuation of the same or similar features in the spatial and temporal dimensions, i.e. between languages, dialects, and between centuries, especially when the standard form does not or cannot penetrate a dialect, as for example, in Aegean Macedonia. Observing the phonetics of various dialects of the central Balkanic area (i.e. the area of Macedonia, Greece, Albania, as well as southern Italy) we see a general lack of stabilization, a number of pronunciation options and hesitations. This proves that certain phonetic processes never come to an end because a language can re-borrow its own phenomenon from a language in contact, where this feature developed under the influence of the first language. In the process of borrowing and re-borrowing, such a feature undergoes constant reformulation. Consequently, in most cases we cannot determine precise rules and restrictions but only tendencies, more or less clearly expressed. In some dialects historical processes are still active and restrictions are without exceptions, whereas in some other neighbouring dialects the same phenomena function in a different way. Some dialects borrow a phonetic fact only partially, sometimes they lose it in time, sometimes not, or the fact is petrified in a number of lexical forms but not in all parallel phonetic contexts, which means that it does not become a rule. Permanent multilingualism often causes reciprocal influence and constant fluctuation between languages. As a result, the situation may not be stable, certain processes never end; they sometimes reach their target point, but very often they do not; they may also repeat. Constant hesitations and the occurrence of double forms are the most striking phenomena regarding certain phonetic facts in certain dialects. Options and hesitations penetrate even the standard form of Macedonian. Depending on a feature, the lack of stability may occur in the whole language or in a particular dialect. This means that we can observe here a continuation of certain specifically Balkanic phenomena on various levels. Altogether this gives a rather colourful picture of the Macedonian phonetics. However, to be able to see this, we have to treat the linguistic material in a way which a regular 
linguist would describe as lacking in methodology, mixing synchrony and diachrony, as well as mixing various forms of a language: standard, colloquial, dialectal.

Bearing in mind the above, it is not astonishing that the Balkanic phonetic features do not fully overlap with the Balkan Sprachbund as defined by the morphosyntactic features. According to morpho-syntax, the Balkan Sprachbund consists of Romanian, Bulgarian, Macedonian, Albanian, Greek and other ethnolects spoken in the area encompassed by these languages. As far as phonetic facts are concerned, the Balkan Sprachbund can be divided into three parts: 1 . The Eastern one which, in fact, constitutes the southern exposure of the Euro-Asiatic phonetic Sprachbund (Jakobson 1962). This very area was once postulated as typically Balkanic (Ivić 1968), probably because of its distinctiveness in comparison to the rest of Europe. 2. The Central area, with opposite features, which are closer to the Western European languages. This area has also some specific Balkanic features. 3. The Mediterranean Sprachbund to which all languages of the northern Mediterranean peninsulas belong to a lesser or greater degree.

Romanian and Bulgarian dialects, especially eastern Bulgarian, belong to the Eastern part. This region is characterized by the accommodative type of pronunciation. This means that various assimilations and neutralizations occur in these dialects, mainly palatalizations and vowel reductions. Some of these features reach as far as to the northern Greek dialects. Vowel reductions in Greek are even stronger than in Bulgarian (high unstressed vowels are lost and middle vowels shift into the high ones). The scope of assimilative palatalization varies depending on the type of passive consonants, on the vocalic context and on a dialect. This area - the Euro-Asiatic Sprachbund - was characterized by Roman Jakobson (1962) by frequent palatalizations and the lack of polytony.

Mediterranean dialects - southern Greek, southern Italian dialects, and most of Iberic dialects - have an open syllable pattern, or rather relatively open (which means that only a vowel or a single consonant can stand word finally). Which consonants can stand word finally depends on a language - more often these are single sonants. Final obstruents or consonantal clusters are extremely rare and they occur only in a few loans. However, their pronunciation is usually quasi syllabic - they are followed by a kind of vocalic echo - the phenomenon which is most distinct in Portuguese. Catalan and Occitan do not have this feature - it is a consequence of the reduction of unstressed final vowels. On the other hand in Czakavian, the final consonantal coda is very often simplified under the Italian influence.

The second feature of the region is the restriction on intervocalic voiced stops, which is a result of historical lenition of voiced stops as in Greek, 
or dialectal or colloquial fricativization, loss or replacement of stops, as in the Romance languages. Today, what unifies Greek with these Romance languages is the restriction on intervocalic voiced stops. This feature regards either the standard form of a language (Greek), the usual pronunciation practice (Iberic), or colloquial and dialectal speech (Italian). Today it is not present in Northern Greek (mainly as a result of the simplification of the intervocalic clusters 'nasal sonant + homorganic stop' into a single stop); however, it radiates into Macedonian, where, in dialects, a number of consonants undergo lenition. Fricative pronunciation of intervocalic voiced stops happens even in the colloquial pronunciation of the standard form.

The Central area is the most specific. It is characterized by a number of features opposite to those of the Eastern area, which makes the phonotactics more similar to that of the rest of Europe. This area consists of the juncture of Slavic Macedonian, Albanian, Greek and Aromanian. The features of this region concentrate just here, however, the scopes of particular features do not overlap, and some of these features extend far beyond this region. The most characteristic feature is a set of phenomena connected with the functioning of the clusters of a nasal sonant with a homorganic stop. I shall discuss this in greater detail later on.

As we see, the Greek language participates in all three areas. The Eastern and Mediterranean areas are slowly disappearing because of the influence of the standard forms and the influence of English, and, generally, Europeization.

Obviously, in this paper, we shall turn our attention to the features that survived, i.e. to continuity rather than to discontinuity. Sometimes, when the results of a process are stabilized, it is possible to note a plain fact about a language. At other times, we can observe an ongoing process. In the latter case constant options occur - such a situation may last in a dialect even several centuries.

As can be seen, the Macedonian linguistic area belongs to the Central Balkanic region. It has all its specific features. These are the features that are opposite to those of the Eastern area - the fact that localizes Macedonian within a different phonetic type and a different Sprachbund than Bulgarian. However, it must be stressed that there is no sharp boundary between the two regions in question. Thus, there is no definite boundary between Macedonian and Bulgarian phonetics. The same regards boundaries between all South Slavic languages - transitions between them are always gradual. Consequently, the transition between phonetic types is gradual as well. A dialect may belong to a type or a Sprachbund to a certain degree.

As mentioned above, the standard form of Macedonian has all relevant features of the Central Balkanic area. These features include: 
- Accommodation is very restricted. Most importantly, there is no assimilative palatalization. In Macedonian only velar stops undergo very light assimilation before front vowels, which is a relative universalism (the only exception known to me is the Czech language). According to the literary norm, these palatalizations must not lead to the merger between velars and palato-velars $\kappa, z ́([c],[y])$. Hard lateral [ł] before front vowels becomes rather semi-soft. It sounds similar to, for example, Polish [1] - the sound which is considered a hard consonant.

- The number of palatal phonemes is five: three sonants and two obstruents (in Bulgarian all hard consonants have their soft counterparts as independent phonemes). They all have a very low frequency. Jota makes the only exception. Apart from that there appears a strong tendency to further decrease the frequency of palatals or even to the elimination of palatal phonemes. [n] is usually pronounced as semi-soft, and word finally it is already hard (cf. [sin], [kon] instead of earlier [sip], [kon]. In Macedonian words [n] appears only between vowels and extremely rarely close to a consonant but only in the middle of words, cf. мольь which can be also pronounced as [mołnija]. Also the phoneme $/ \Lambda /$ can be pronounced with various degrees of softness, including non-palatal, the so-called middle European lateral, and in some dialects it has even become a hard velar. All palatal phonemes have a very low frequency: / $\mathrm{J} /$ and /n/ - 0,12\% each, /c/ - 0,61\%, /K/ - only 0,02\% (Джукески 1955). /j/ is more frequent, but it is weak in a number of positions. Especially in intervocalic positions it may be omitted, or at least double forms appear (with and without [j]). Parallels are found in neighbouring Albanian and Northern Greek dialects (for details see Sawicka 1997).

- The merger of affricates is a common feature of the whole Central Balkanic region. Serbian [tc], [dъ], Albanian and Macedonian [c], [f] are becoming hard and fuse with [t]], [d]]. The process is especially evident on the dialectal level. In standard Macedonian the pronunciation of $/ \mathrm{c} /$ and $/ \mathrm{J} /$ varies between $[\mathrm{c}],[\mathrm{f}], \mathrm{t}],[\mathrm{d}]$ ] and $[\mathrm{f}],[\mathrm{d}]]^{1}$.

- Other assimilations are also rare. The most important is the character of the Macedonian sandhi. In Slavic languages this term regards first of all voicing and devoicing. In comparison with most Slavic languages, in Macedonian these phenomena are restricted. Namely - at least according to the standard norm -regressive assimilation occurs only before obstruents. In practice, however, it happens also before resonants.

1 The Standard form of Greek has no palatal obstruents. However, in Northern dialects they may emerge from velars as a result of assimilative palatalization before front vowels. These allophones, depending on a dialect, are pronounced as pure palatals, semi-palatal sounds or even hard affricates. Mutatis mutandis the same regards Turkish Balkanic dialects (see Sawicka 1997: 43). 
Besides, voicing and devoicing is not a regular fact in any context (see Korytowska 2001, 2007, Komparacja..., s. 183). An important fact is that sandhi depends not only on the segmental context, but also on the tempo of speech and on the realization of pauses. Thus, it depends on actually existing conditions of phonetic production. Consequently, it is a live process, which distinguishes Macedonian from the majority of other Slavic languages where sandhi constitutes a set of synto-phonemic rules. Such a semi-sandhi is very characteristic of the central part of the Central Balkanic area. The same character has the Northern Albanian sandhi, in opposition to standard and Southern Albanian where sandhi is consistent. Similar (but not identical) situation as in Macedonian is found in the Greek dialects from Aegean Macedonia where, after the loss of unstressed final high vowels, conditions for sandhi emerged (Korytowska 2009, Mарүарıтп-Pоүка 1985, 1990). In standard Greek (where there is only one obstruent /s/ at the end of prosodic units) sandhi is not regular either. Certain parallels with Greek are also observed in Macedonian, namely, voiced obstruents become voiceless more often before vowels than before sonants, which is a rule in Greek.

- Another feature which can be associated with the non-accommodative character of speech is the lack of the so-called vocalic reductions. The scope of this feature is different from the previous one. This time Macedonian joins the Sztokavian dialects, whereas Northern Greek dialects have strong vocalic reductions. Perhaps Northern Albanian can also be considered as characterised by this feature - it usually has no vowel where Southern Albanian has a reduced unstressed vowel $(\ddot{e})$, although the character of the reduction is different in Greek (where it is similar to Bulgarian) and in Albanian.

- The next feature is the loss of [x] (see for example Bulg. хубаво - Mac. убаво. [x] in Macedonian appears exclusively in foreign terminology, cf. хемија. Also this feature is not shared with Greek, but with Serbian and Albanian, especially Northern Albanian. Serbian and Albanian have $[\mathrm{x}]$ in their standard forms, but dialects and very often colloquial usage do not have it. In Slavic dialects it is replaced by [j] (cf. Serb. [snaja] for [snaxa]) or [v] ([uvo] for [uxo]). Some of these forms have entered the standard form. In Albanian usually [f] replaces [x]. In standard Albanian, however, $[\mathrm{x}]$ is preserved in certain positions, cf. [nox] 'I know' but [noftim] 'knowledge'. In Northern Albanian the scope of the loss of $[\mathrm{x}]$ is much wider. In Macedonian $[\mathrm{x}]$ may be replaced mainly by [v], [f], [j] or zero.

- Geminate consonants are very rare in all Balkanic languages and in Southern Slavic, including the Czecho-Slovak group. In the Central 
Balkanic region, including Macedonian, they are extremely rare. They may appear only on very strong morphemic boundaries, that is between words and inside prosodic words before or after clitics and in compound words. However, even in these positions they cannot constitute threesegmental clusters with any other consonant, cf. Mac. padocma for padocm $+m a$, Serbian besmislen for bez + smislen. Rumanian also accepts geminates on prefixal boundaries and in compounds. On both sides of this large area geminates have an extremely high frequency, that is, in Italian, Turkish and also in the Geek dialect of Cyprus. In the Balkanic area Bulgarian constitutes an exception. Although geminates in the domestic Bulgarian material also occur on morphemic boundaries only, their number and frequency is much higher than in the remaining Balkanic area. Moreover, Bulgarian sometimes accepts geminates in loans.

- Word stress in the languages of the area tends to stabilize as paroxitonic, proparoxitonic or oxitonic. In Macedonian it is already stabilized on the third syllable from the end of the word.

- A very characteristic feature of the Central Balkanic area is a set of phenomena linked with the ND clusters (nasal sonant + homorganic stop, see below).

- One more Balkanic feature is a high frequency of vocalic clusters. It is especially evident when we compare Northern Slavic languages (including Slovenian and Czecho-Slovak group) with Southern Slavic. The difference is striking. A. Korytowska investigated the problem. She counted vocalic clusters on four comparable pages of each Slavic language and divided them into three groups: languages that preserved old Slavic prostheses (less than $10 \mathrm{VV}$ clusters), remaining Slavic languages without the Balkan group (between 10 and $30 \mathrm{VV}$ clusters), and Balkanic languages with over 50 VV clusters (Korytowska 2001, 2007, Komparacja... 2, s. 202). Macedonian is characterised by this feature to the greatest degree. The high number of VV clusters is due to the loss of intervocalic ${ }^{*} x$, and to the influence of Greek. In Greek the intervocalic iota is lost before front vowels. The same is observed in Bulgarian and Macedonian. Moreover, as far as this feature is concerned, Macedonian is extremely diversified. This means that in the dialectal or colloquial speech the hiatus may be either filled or not and that the intervocalic etymological iota (and sometimes other consonants too) may be either omitted or not. This results in a number of options and double forms. The standard norm does not introduce much order in this respect.

As can be seen, the majority of the features are concentrated in the middle of the area - where western Macedonian, Greek and Albanian meet. However, 
the scopes of particular features do not overlap. Some of them occur only in the central part, some other radiate far beyond the centre and in various directions. Consequently, a language with respect to a certain feature may belong to one area, but with respect to another feature it may fall within another area. The Greek language constitutes a striking example (see above). As we see, a language as a whole may share particular features with various languages. Apart from this, particular dialects of a language may belong to different types and different Sprachbünde. Such is the case of the Serbian language, the southern and south-eastern dialects of which have the complete list of morphosyntactic balkanisms, whereas the standard form has only a few of them. In this way, Serbian is an example of the simultaneous continuity and discontinuity of the old, original structure. Balkanic structure is a new one and expanding. Consequently, it is hard to speak about discontinuity if what we have in mind is the Balkanic grammar. If it enters a language, it stabilizes for good. It is not so when phonetics is concerned. This is due to the differences between convergence on the grammatical and phonetic levels. As already mentioned, phonetic convergence very rarely penetrates the function; usually it is restricted to pure form itself. Thus, such a convergence may proceed faster and may not be stable, especially when its results are not accepted by the literary norm. The phonetic balkanisms may be ephemeral. However, they may survive in dialects if they are successful in entering the linguistic code (which is usually connected with distributional properties). Such is the situation of the Macedonian dialects in Greece and Albania which suffer from the influence of Greek and Albanian and are immune to the influence of the literary norm of Macedonian. In these dialects certain old phonetic balkanisms have survived. Thus, in the case of Macedonian we can speak about both continuity and discontinuity of balkanization on the phonetic level. To notice such facts the researchers of areal studies should not only list facts, but also follow the processes of convergence. This means that in some cases the research cannot be restricted to the synchronic level, and it cannot be restricted to the standard forms. Very often we have to compare the standard form of a language with a dialect of another language. This also means that each feature needs a broad commentary. Such an approach could meet with objection on methodological grounds. If we proceed in such a way we shall see that the Balkan phonetics does not originate from a particular language idiom, but that each of the Balkanic ethnolects, including Balkan Latin, contributes to its formation. There are even features the origin of which may be associated with several different idioms - their functioning constitutes the resultant of similar but originally different phenomena. Only in such a way can we interpret, for example, the functioning of the clusters [nd], [ng], [mb] in the Balkanic languages (see below). Their occurrence is 
a result of several different processes, and their place in the phonemic and distributional systems is diversified.

It is also evident that Bulgarian and Macedonian phonetics belong to distinctly different types, although a sharp border line between them cannot be established. Generalizing: what certainly links these two languages are the Balkanic morphosyntactic features and this fact makes the historical relationship between Bulgarian, Macedonian and Serbian a bit unclear, because these idioms were probably not yet differentiated clearly when balkanisms began to penetrate them ${ }^{2}$. Today the Macedonian phonetics is much closer to the Serbian phonetics than to the Bulgarian one. Macedonian shares with Serbian a restricted number of palatal consonant phonemes, the lack of assimilative palatalization, the lack of consonantal gemination, the lack of $[\mathrm{x}]$, the lack of a centralized vocalic phoneme, and the lack of vocalic reductions. All these features occur in Bulgarian. Apart from this, the merger of affricates occurs both in Serbian and Macedonian. Macedonian shares with Bulgarian only the common south Slavic features: the so-called one peak syllable pattern and a very high frequency of vocalic clusters. What differentiates Serbian and Macedonian are the features which can be thought of as transitional in character. This is the kind of sandhi - Serbian has no sandhi, Bulgarian has a full type of sandhi, whereas Macedonian has a restricted form of sandhi. The second feature concerns long vowels as separate phonemes which exist in Serbian, but not in Bulgarian. Macedonian does not have such phonemes, but it has an extremely high frequency of vocalic geminates which some linguists tend to treat as phonemes (Пјанко 1960/1961) ${ }^{3}$. As can be seen, most of the common Macedonian-Serbian features are the features characteristic of the Central Balkanic area. What differentiates Macedonian from both Serbian and Bulgarian are the procliticization of the clitic form of personal pronouns and the kind of word stress. Additionally, Macedonian has certain specific Balkanic features which Bulgarian and Serbian do not have; these are the two "classical" phonetic balkanisms.

Describing the Balkan Sprachbund scholars usually add two phonetic features to the morphosyntactic characteristics. The first one is the occurrence of a centralized extra-short vocalic phoneme. The second one is the occurrence of clusters $n d, \eta g, m b$ and $n t, \eta k, m p$ in the word initial position. Today, centralized vowels as separate phonemes exist in Bulgarian,

2 Probably the only way to determine which language was closer to Macedonian in the past is to compare the basic lexicons of the three languages.

3 It should be repeated here again that there are no sharp boundaries between Serbian and Macedonian, Macedonian and Bulgarian, as well as between Bulgarian and Serbian phonetic types. The existence of transitional zones is evident. Even in the speech of Belgrade we can often observe the lack of polytony, the loss of long vowels and a kind of vocalic reductions. 
Rumanian and also in southern Albanian. With regard to the occurrence of such a phoneme, Bulgarian and Rumanian are typologically linked with northern Slavic languages where a similar vowel [i] has undergone phonologization. Consequently, from the synchronic perspective, it is not a characteristic feature of Balkanic languages, but rather of the Jakobson's Euro-Asiatic Sprachbund, and it is evidently linked with a higher participation of palatalization in phonetic systems. However, when we look into historical grammars of the Balkanic languages we see that such a vowel, tense, centralized, and nasal in addition, is found at various stages of the development of all classic Balkanic languages (i.e., Bulgarian, Macedonian, Rumanian and Albanian), and in restricted regions of the Central area it can still be found. Thus, the feature drifts from century to century, from language to language or dialect. In such a way it unifies the area, which, synchronically is rather diversified. This very feature has been preserved in the Slavic dialects of Aegean Macedonia in a very special form. The phenomenon constitutes a combination of the two phenomena in question (see below).

The second feature - initial clusters with initial nasals - exists in Albanian, especially southern Albanian, in southern Italian dialects and in emotionally marked southern Greek. However, its peculiar distribution does not exhaust the subject, which calls for a reformulation. Everything connected with the functioning of the clusters in question should be unified in one feature, which appears to be very original against the European background. The occurrence of these clusters in initial positions is only one among several manifestations of this feature. The feature consists of a number of facts, which fuse sometimes and contribute to the remarkably high frequency of these clusters and to the more or less strongly expressed tendency to the functional equivalence of these clusters. ${ }^{4}$ Their occurrence is also a result of various processes. The most important are two of them: Latin and Albanian reduction and loss of unstressed short vowels and Greek perceptual equivalence of these clusters and voiced stops, but other phenomena also contribute to this (the so-called "buffer consonant" in Greek, Slavic nasal vowels). All this leads, in the perspective of the whole Central Balkanic area, to various options and hesitations, unmotivated prenasalizations of stops, or vice versa, to unmotivated simplifications of the clusters in question when either the nasal is added or omitted, or the stop.

\footnotetext{
4 Other phonetic facts also contribute to this equivalence, which leads to the monophonemic value of the ND clusters. First of all, it is the voicing of stops after nasal sonants (this took place in Greek, Northern Albanian and Southern Italian). Another factor is the assimilation within the cluster (in Southern Italian it is gemmination - ND clusters shift to NN clusters, in Albanian they usually produce long nasal sonants). Such phenomena may contribute to (or just the opposite, they may develop under the influence of) the lack of perceptual difference between D ND NT N. However, such a perceptual and functional equivalence may be postulated only as a tendency.
} 
Returning to the first feature - a centralized phoneme - in Bulgarian, Rumanian, Macedonian and Albanian a phase can be reconstructed when nasalization is linked with centralization. Thus, we postulate the occurrence of a common vowel similar to the nasal schwa (a kind of [ə̃]). We can determine the time of this phase only for Slavic languages. Macedonian material suggests that it could exist only after the vocalization/loss of the Old Slavic jers. Albanian historical grammar mentions the time before the 7 th century. Even if we agree with such a temporal localization, it must be stressed that the rotacism which brought about the end of the existence of nasal vowels never occurred in northern Albanian. Consequently, nasal schwa could last here longer; moreover, one can say that it exists even today (phonetically it is a kind of high, back, nasal and long variety of [ã] that occurs only under the word stress; it corresponds to $\ddot{e}[\partial]$ of standard Albanian). In Rumanian a kind of nasal, higher, centralized vowel emerged from the cluster [an] or [amC]. In the later development nasalization was lost. Today in Rumanian there is a kind of lower schwa that emerged from unstressed [a], and higher schwa developed from [a] before a nasal sonant, regardless of whether it was stressed or not, cf. bìne from Latin bene, linna from lana, čmp from campum, etc. Rumanian $\check{l}$ corresponds to southern Albanian $\ddot{e}[ə]$ and northern Albanian $\hat{a}[\tilde{a}]$ in Latin loans, cf. Alb. mëz/mânz, Rum. m̌̌nz, etc. In Bulgarian, the Old Slavic back (hard) jer fused with the back nasal vowel, cf. $\mathrm{czrH}$ from Old Sl. ${ }^{\star} s ๘ n z, p z \kappa a$ from Old Sl. ${ }^{\star}$ rõka. The merger appears in sources from the 11 th century. In Macedonian the back nasal vowel fused with the secondary vowel which emerged in certain contexts after the loss of weak jers. It is precisely the data from Macedonian that shows us that the fusion occurred after the vocalization/loss of the original jers. In Macedonian, the merger did not comprise the reflex of the strong back jer, because at the time of fusion this jer already sounded like a "full” vowel (cf. сон from Old Sl. ${ }^{\star} s$ s $n$ ) ). Only in the very northern Macedonian dialects, the so-called „u-dialects”, nasals did not fuse with secondary vowels, which means that these dialects did not have such a nasal centralized vowel in their history; here, the back nasal vowel yielded $[\mathrm{u}]$, whereas the secondary vocalism produced [a], cf. pyкa from Old Sl. * rõka, ветар from * [vetr] < Old Sl. * větrz, магла from *[mgła] $<$ Old Sl. ${ }^{\star}$ mbgla, whereas in the standard form and most of the remaining dialects: рака, ветар, магла. At the preceding stage of the development this vowel must have been centralized, extra-short at the beginning, because it developed from a syllabic variety of sonants in certain positions (in the socalled "two-peak" syllables), cf. ${ }^{*}$ mogla $>$ [mgla] (the loss of the weak jer and the emergence of the "two-peak" syllable) > [mgla] (syllabification of $[\mathrm{m}]$ in order to suppress the "two-peak" syllable) $>$ [mogla] (syllabic sonant gives the cluster SV) > магла (further development of the new schwa). But 
was it nasal? It could be a coincidence that the nasal vowel gave the same reflex. However, it was definitely nasal. To prove this we have to come back to the second "classical" balkanism - the ND clusters. As a result of vocalic reductions these clusters occur very often in Albanian and in the southern Italian dialects. They also appear word initially in these languages, cf. Alb. mbret from Latin imperator, ngushtë from angustus, dialectal southern Italian nducere < inducere, mbrellu < ombrello, etc. Papahagi (1963) provides the following Arumanian examples: $n d r e p t u<$ in directo, mpartu < impartire, but Dalametra's and Gołąb's notations suggest syllabicity of nasal sonants in initial position, cf. 'ngîrcat, 'ndreg (Dalametra 1906), ${ }^{\circ}$ mpartu, ${ }^{\circ} \eta k l ' i d u$ (Gołąb 1984). These forms suggest a development such as in Dako-Rumanian, and not as in Albanian (Rum. întreg, impart, etc.). Initial ND clusters occur under Albanian influence in a number of Macedonian villages in southern Albania (cf. [mbleko], [mbravja] examples from Boboshtica). These clusters appear word initially also in the colloquial, emotionally marked utterances in Greek, but here the reason is not the same. In Greek, these clusters have the same systemic value as voiced stops. They are in fact combinatory variations of the voiced stop phonemes. In fact, to an untrained ear of a native speaker, the difference between [b] and [mb], [d] and [nd], etc., is not perceptible. In the case of stop obstruents, the opposition voice vs. voiceless may be reformulated as prenazalized vs. non-prenazalized. Clusters ND occur in the intervocalic positions, whereas in the word initial position varieties without prenazalization occur. However, in emotional speech ND clusters appear in this position as well, cf. [mbes epitelus] instead of [bes epitelus], [ndisu ipa] for [disu ipa], etc. In the colloquial and dialectal Greek these clusters are perceptively and functionally equivalent to corresponding voiced stops. One would rather expect that voiced stops and voiced fricatives form combinatory variations, because in the early history of Greek intervocalic voiced stops underwent lenition and the restriction on the occurrence of voiced stops in this context is still valid. However, today in loans and foreign words, intervocalic voiced stops are not replaced by fricatives but by ND clusters, cf. [panganini] for Paganini. In the colloquial Greek there are not such clusters with voiceless stops (in the domestic lexicon they have undergone voicing). Consequently, loans with intervocalic voiced stops or NT clusters are usually pronounced with ND, cf. [menta] //[menda] and even [meda] (and only the last pronunciation is commonly considered substandard), although in the speech of educated Greeks there exists the opposition /nd/ vs. /nt/ vs. /d/. Such a situation influenced Aegean Macedonian dialects, although in northern Greek dialects the ND clusters were later simplified to single stops. ${ }^{5}$

5 Today northern Greek has new ND and NT clusters. They emerged as a result of the loss of unstressed high vowels. On the other hand, the Macedonian material suggests that after the loss/ 
In several Macedonian villages in Greece and in south-western Macedonia, the Old Slavic nasal vowels are preserved in the form of ND (or NT) clusters, but nasalization (that is $\mathrm{N}$ ) is preserved only before stops, cf. dambi, grandi or dambi, grandi, etc. The link with Greek is obvious. But is this linked with centralization? Absolutely yes! Why not if it is so in other Balkanic languages? Besides, the secondary centralized vowel receives the same nasal reflex in the same villages and only before voiced stops - in these villages магла sounds [mangła] or [məngła]. Here we do not find any etymological link between nasalization and centralization. Nasalization is automatically associated with centralization (see the merger in Bulgarian and identical reflexes of the back jer and back nasal vowel in standard Macedonian).

In some villages in Aegean Macedonia nasalization may appear in other contexts too. If the Old Slavic back jer preserved its original phonetic character, (i.e. a centralized, extra short vowel), it can also have a nasal reflex today before stops. The scope of nasalization may be enlarged also by a typical north Greek phenomenon, the so-called "buffer consonant." It is an infixed stop, breaking clusters of a sibilant and a sonant or a cluster of two sonants, cf. Greek [xamomilo] which produces in northern Greek [xamomlu] and then [xamomblu], Slavic dialectal [zdrebe] instead of [zrebe], etc. Clusters of a nasal sonant plus fricative emerged in Southern Macedonian after the decomposition of nasal vowels and in several villages of eastern Aegean Macedonia they have got infixed stops. As a result, nasal sonants occurred before stops which is the context conditioning the preservation of nasalization, cf. Old Slavic ${ }^{*}$ mẽso $>$ [menso] $>$ [mentso] and finally [mentsu], ${ }^{\star}$ gõsb $>$ [gəns] $>$ [gənts] $>$ [gənts]. What proves that nasalization was automatically associated with centralization is the fact that sometimes the same sounds developed from the original jer, $\mathrm{cf} .{ }^{\star} b z z z>$ [bəs] $>$ [bə̃s] $>$ [bəns] $>$ [bənts] $>$ [bənts]. The infixed [m] is common in Albanian dialects in the $m r$ and $m l$ clusters (cf. [numbri], [zombra] instead of numri, $z \ddot{e} m r a)$ - the same occurs in Macedonian dialects in southern Albania, cf. [mbleko], [umbrjał], [mbravja] etc., (for details see Савицкая 2000, 2002).

The Macedonian language has undergone marked changes under the Greek influence - it preserved its own nasalization before stops, although it has intervocalic voiced stops without prenasalization, too. On the other hand, it has nasal sonants (from nasal vowels) before voiced as well as before voiceless stops, whereas in Greek stops underwent voicing after nasal sonants. In Macedonian dialects stops very rarely undergo voicing after nasal sonants, cf. [pajangu]. Very rarely are nasal sonants preserved exclusively before voiced stops, but the deciding factor is usually the etymological value

vocalization of Slavic jers northern Greek dialects still had the ND clusters unsimplified. 
(thus, for example [dambi] and [damp]). Also, the actual phonetic value of the stop extremely rarely constitutes a relevant context, cf. [dambi] but [dap] (the situation described by Иллич-Свитыч 1962). Thus, the contemporary scope of the phenomena that testify to the identification of centralization with nasalization in a certain period in Balkanic dialects, and, additionally, the merger of this phenomenon with the Greek identification of voiced stops with ND clusters, varies: in some dialects this link is more evident, in some others not evident at all. Nevertheless, such a link in the Middle Ages can be evidenced for the whole Macedonian area (with the exception of the $\mathrm{u}$-dialects), the same as for Bulgarian, Rumanian and Albanian.

Now we can come back to the first classic Balkan feature - the nasal schwa. As we see, Macedonian continues in a way the old phonetic balkanism. Besides, some of the Macedonian dialects near Thessaloniki still have an extra short, tense vowel with a timbre of nasalization. It is probably similar to the original vowel in question. Summarizing: a part the Macedonian linguistic area shows a more evident continuation of this balkanism, whereas for the remaining Balkan area a kind of nasal schwa can be only reconstructed.

The scope of this old phonetic balkanism overlaps more or less with the scope of the morphosyntactic balkanic features. I am inclined to think that it covers the area of the Proto-Albano-Rumanian substratum. Latin settlements were also more concentrated in this area. If such a conception is realistic, we are able to delimit quite precisely the area of the donor language of the Balkan language structure and, naturally, we are in position to draw further conclusions regarding the Albanian language.

One more verycharacteristicfeature of the CentralBalkanic area(including southern Italian dialects) are constant replacements of consonants, especially in intervocalic positions. Among these processes we find, first of all, mutual replacements of palatal consonants, lenitions, insertions of unmotivated consonants between vowels, as well as the loss of intervocalic consonants. With respect to this problem, Macedonian phonetics is very unstable. As far as the loss/insertion of the iota is concerned, even the standard form is not consistent. The same morphemes appear with or without iota (cf. греалка but грејач). Words may have double forms, as Деан and Дејан. The official norm specifies that the iota between two vowels, one of which is a front vowel, has no phonemic value. At the same time the norm states that between two vowels, one of which is a front vowel, a more or less distinct (non-phonemic) iota can be inserted. The same is said about initial front vowels which can be pronounced with a weak prosthetic iota. According to Macedonian phonemic rules, the iota is always phonemic before back vowels; consequently, it should not be omitted or inserted into clusters of two back vowels (Конески 1982). In practice, however, the pronunciation 
of these clusters is not stable either. In addition, there are contexts where /i/ may be pronounced as [j]. In regional speech and, especially, in dialects, the repertoire of such mutual replacements, options and hesitations is much wider (VV pronounced with or without [j], with or without [v], etc.; other consonants may also undergo lenition or complete reduction, etc.; for details and further bibliography see Sawicka 2000). All this contributes to a very high number of vocalic clusters in Macedonian texts - the feature which we consider one of the Balkanic features of the Central Balkanic area. Perhaps it is not only the high number of VV, but also the lack of stabilization and the uncertain phonemic status of the iota that should be considered as a Balkan feature. The same problems, concerning the phonemic value of the iota, pertain to the Greek phonology (Setatos 1969). Certainly the Greek language influenced the Macedonian situation, especially northern Greek dialects, where the intervocalic iota has been lost before front vowels (Newton 1972). Per analogiam, in the same morphemes the iota can be lost also before back vowels (cf. $\varepsilon \varphi \alpha \gamma \alpha$ [efaa] 'I ate', because $\varepsilon \varphi \alpha \gamma \varepsilon$ [efae] 'he ate'). Because VV with the second back vowel may occur with and without the intervocalic iota, an unmotivated [j] or [v] may be inserted into any type of VV. All other phenomena concerning the pronunciation of vocalic clusters, the phonemic status of the iota, and the phonemic relation $[\mathrm{i}] \sim[\mathrm{j}]$ are also the same in Macedonian and northern Greek. ${ }^{6}$ Summing up, this is an unsolved problem of the Macedonian phonology and, in fact, it cannot be satisfactorily solved. It exemplifies the most characteristic situation of the Balkan phonetics the process that never ends, because it consists in functional equivalence of certain contexts; consequently, it triggers contradictory changes - filling in the hiatus and omitting the etymological iota (the same may be said about the equivalence of ND/D, see above). Even if in a dialect the situation tends to stabilize, a neighbouring foreign dialect may reintroduce it. Sometimes even standardization fails to straighten up this mess.

To conclude, in the Macedonian dialects and sometimes even in standard Macedonian, we find the continuation of all relevant Balkanic phonetic processes - processes that never come to end.

Dalametra I.

\section{References}

(1906) Dicționar Macedo-Român, București.

Décsy G.

(1973) Die linguistische Struktur Europas, Vergangenheit - Gegenwart - Zukunft, Wiesbaden.

6 This is an extremely complex problem, connected with a number of other similar processes, which situates it well beyond the scope of this paper. 
Джукески А.

(1955) Процентуалната состојба на гласовите во македонскиот литературен јазик, „Македонски јазик” VI, pp. 165-201.

Gołąb Z.

(1984) The Arumanian Dialect of Kruševo in SR Macedonia SFR Yugoslavia, Skopje.

Haarman $\mathrm{H}$.

(1976) Aspekte der Arealtypologie. Die Problematik der europäischen Sprachbünde, Tübingen.

Иллич-Свитыч М. В.

(1962) О стадиях утраты ринезма в югозападных македонских говорах, „Вопросы славянского языкознания" 6, pp. 76-88.

Ivić $\mathrm{P}$.

(1968) Liens phonologiques entre les langues balkaniques, [in:] Actes du premier congres international des etudes balkaniques et sud-est europeennes, Sofia, pp. 133-143.

Jakobson R.

(1962) К характеристике евроазийского яызкового союза, [in:] Selected writings I, Mouton \&'s-Gravenhage, pp. 144-202.

Конески Б.

(1982) Граматика на македонскиот, литературен јазик, Скопје.

Korytowska A.

(2001) Grupy samogłoskowe w językach słowiańskich, dysertacja doktorska, niepublikowana, Uniwersytet Mikołaja Kopernika, Torun.

(2006) Zjawisko sandhi w języku macedońskim, „Folia philologica Macedono-Polonica" 7, Poznań, pp. 71-75.

(2007) Grupy samogłoskowe w bałkańskich językach słowiańskich, [in:] Z polskich studiów slawistycznych, Językoznawstwo, Warszawa, 83-90.

(2009) Sandhi w literackim języku albańskim na Kosowie, Linguistica „Copernicana” 1, pp. 223-231.

Марүарıтп-Роүка M

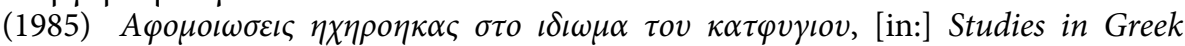
linguistics, Proceedings of the Xth annual meeting of the Department of Linguistics, 8-11 May, 1989, Thessaloniki, pp. 151-168.

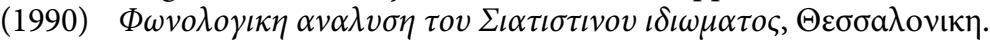

Newton B.

(1972) The Generative Interpretation of Dialect. A Study of Modern Greek Phonology, Cambridge.

Papahagi P.

1963 Dicționarul dialectului Aromîn general şi etimologic, București.

Пјанко B.

(1960-1961) Квантитетот како фонолошки фактор во македонскиот јазик, „Македонски јазик” XI/XII, pp. 203-213.

Sawicka I.

(1997) The Balkan Sprachbund in the Light of Phonetic Features, Warszawa.

(2000) Problemy zwiazane $z$ interpretacja fonologiczna grup samogłoskowych $w$ macedońskim i polskim, "Folia philologica Macedono-Polonica" 5, Warszawa, pp. 149-157. 
(2000) Ободном средневековном балканизме, „Материалы XXVIII Межвузовской научно-методической конференции преподавателей и аспирантов, вып. 21, Балканские исследования, част 3", март 1999, Санкт Петербург, pp. 25-28.

(2002) Функционирование групп согласных типа НД в балканских языках, [in:] Материаль конференции посвещенной 90-летию со дня рождения Агнии Васильевны Десницкой, Санкт-Петербург, pp. 195-198.

(2007) Arealines fonetikos (fonetines geografijos) ivadas, Vilnius.

Sawicka I. (ed.)

(2007) Komparacja wspótczesnych języków słowiańskich 2, Fonetyka ifonologia, Opole. Setatos M.

(1969) Phonological Problems of Modern Greek Koine, Thessalonike.

\section{Ciągłość czy jej brak - casus macedońskiej fonetyki}

Nadrzędny temat dotyczący ciągłości zjawisk przedstawiony został na materiale macedońskiej fonetyki. Fonetyka macedońska została rozpatrzona jako składnik fonetyki Europy południowo-wschodniej, a nie jako element świata słowiańskiego. Przedstawiono, po pierwsze, obraz statyczny, wynikający $\mathrm{z}$ wyliczania relewantnych typologicznie cech. Ten obraz klasyfikuje fonetykę macedońską jako składnik centralnego obszaru bałkańskiego. Po drugie, położono akcent na przebieg procesów konwergencyjnych w zakresie fonetyki i na różnice w stosunku do takich procesów w zakresie gramatyki. Wynika z nich: nietrwałość cech fonetycznych, a w każdym razie ogólnie mniejsza trwałość cech fonetycznych niż cech morfo-składniowych, ale też możliwość przetrwania pewnych zjawisk na małych obszarach, w paru gwarach, możliwość powracania cech fonetycznych, co wynika z naprzemiennej interferencji międzydialektalnej. Terytorium języka macedońskiego obfituje w takie sytuacje ze względu na większą multietniczność niż gdziekolwiek indziej na Bałkanach. Szczególny pod tym względem jest obszar Macedonii Egejskiej, gdzie dialekty słowiańskie są „zabezpieczone” przed działaniem normy literackiej. Chociaż w wypadku języka macedońskiego nawet realizacja normy literackiej pod względem fonetycznym nie jest całkiem stabilna. 